\title{
Ev İçi Radon Aktivite Konsantrasyonu ve Kanser Riski
}

\author{
Pelin OTANSEV* \\ İstanbul Üniversitesi, Fen Fakültesi, Fizik Bölümü, İstanbul \\ (ORCID: 0000-0003-0766-649X)
}

\begin{abstract}
Öz
Bu çalışmada, İstanbul ilinin çeşitli semtlerinde ev içi radon aktivite konsantrasyonları LR-115 pasif iz detektörler

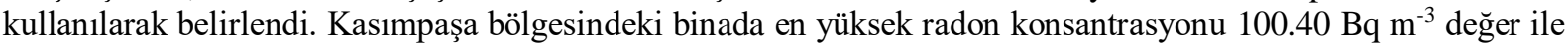
1. katta belirlenmiştir. Sefaköy’ deki binada radon konsantrasyonu binanın 5. katı hariç üst katlara doğru azalmıştır. 5. katta radonun yüksek olmasının nedeni zayıf havalandırma olabilir. Bahçelievler' de 1. kattaki radon konsantrasyonu 5. kattan daha yüksektir. Esenyurt' ta 2. kattaki radon aktivitesi 1. kattan daha yüksektir ve bu havalandırma şartlarından kaynaklanabilir. Kasımpaşa, Sefaköy, Bahçeşehir, Bahçelievler ve Esenyurt' taki binalarda belirlenen radon aktivite konsantrasyonları Türkiye Atom Enerjisi Kurumu tarafindan belirlenen $400 \mathrm{~Bq}$ $\mathrm{m}^{-3}$ limit değerin altındadır. Kolmogorov-Smirnov normalite testine göre, binalarda belirlenen radon aktivite konsantrasyonları normal bir dağılım göstermektedir. En düşük ve en yüksek yıllık etkin doz eşdeğeri $0.8 \mathrm{~m} \mathrm{~Sv} \mathrm{y^{- }}$ ${ }^{1}$ ve $3.17 \mathrm{~m} \mathrm{~Sv} \mathrm{y}^{-1}$ olarak belirlendi. Kanser risk değerleri $0.28 \times 10^{-3}$ ve $11.10 \times 10^{-3}$ arasında elde edildi.
\end{abstract}

Anahtar kelimeler: Radon, Kanser riski, İstatistik parametreler.

\section{Indoor Radon Activity Concentration and Cancer Risk}

\begin{abstract}
In this study, indoor radon activity concentrations in various districts of Istanbul province were determined using LR-115 passive track detectors. In the building in Kasımpaşa region, the highest radon concentration was determined in the 1st floor with a value of $100.40 \mathrm{~Bq} \mathrm{~m}^{-3}$. In the building in Sefaköy, the radon concentration decreased towards the upper floors except the 5th floor of the building. The reason why radon is high in the 5th floor may be poor ventilation. In Bahçelievler, the radon concentration in the 1st floor was higher than the 5th floor. In Esenyurt, the radon concentration in the 2nd floor was higher than in the 1st floor, and this may be due to ventilation conditions. The radon activity concentrations determined in buildings in Kasımpaşa, Sefaköy, Bahçeşehir Bahçelievler and Esenyurt were below of $400 \mathrm{~Bq} \mathrm{~m}^{-3}$ limit value declareted by the Turkish Atomic Energy Agency. According to the Kolmogorov-Smirnov normality test, the radon activity concentrations determined in the buildings show a normal distribution. The lowest and the highest annual effective dose equivalent were determined as $0.8 \times 10^{-3}$ and $3.17 \times 10^{-3} \mathrm{~m} \mathrm{~Sv} \mathrm{y}^{-1}$. Cancer risk values were obtained between $0.28 \times 10^{-3}$ and $11.10 \times 10^{-3}$.
\end{abstract}

Keywords: Radon, Cancer risk, Statistics parameters.

\section{Giriş}

Bütün canlılar, karasal kökenli iyonlaştırıcı radyasyon ve güneş sisteminden kaynaklanan kozmik ışınların zararlı etkilerine maruz kalmaktadır.

4,5 milyar y1l önce dünyanın oluşumundan bu yana toprakta doğal olarak mevcut olan ve toprağın radyoaktif olmasına neden olan doğal radyonüklitlerden en önemlileri ${ }^{238} \mathrm{U},{ }^{232} \mathrm{Th} v \mathrm{ve}^{40} \mathrm{~K}$ dur. Bu radyonüklitlerin çevrede dağılımı bölgenin jeolojisi ve coğrafi durumuna bağlı olarak değişmektedir $[1,2]$. Radonun doğada en çok bulunan iki izotopu ${ }^{222} \mathrm{Rn}$ ve ${ }^{220} \mathrm{Rn}$ ' dir. ${ }^{222} \mathrm{Rn}$, yarı ömrü $4,56 \times 10^{9}$ yıl olan

\footnotetext{
*Sorumlu yazar: pelins@istanbul.edu.tr

Geliş Tarihi: 30.01.2021, Kabul Tarihi: 29.04.2021
} 
ve yer kabuğunda doğal olarak bulunan radyoaktif ${ }^{238} \mathrm{U}$ 'in bozunma zincirinin bir halkasıdır. Şekil 1'de uranyumun bozunma zinciri verilmiştir.

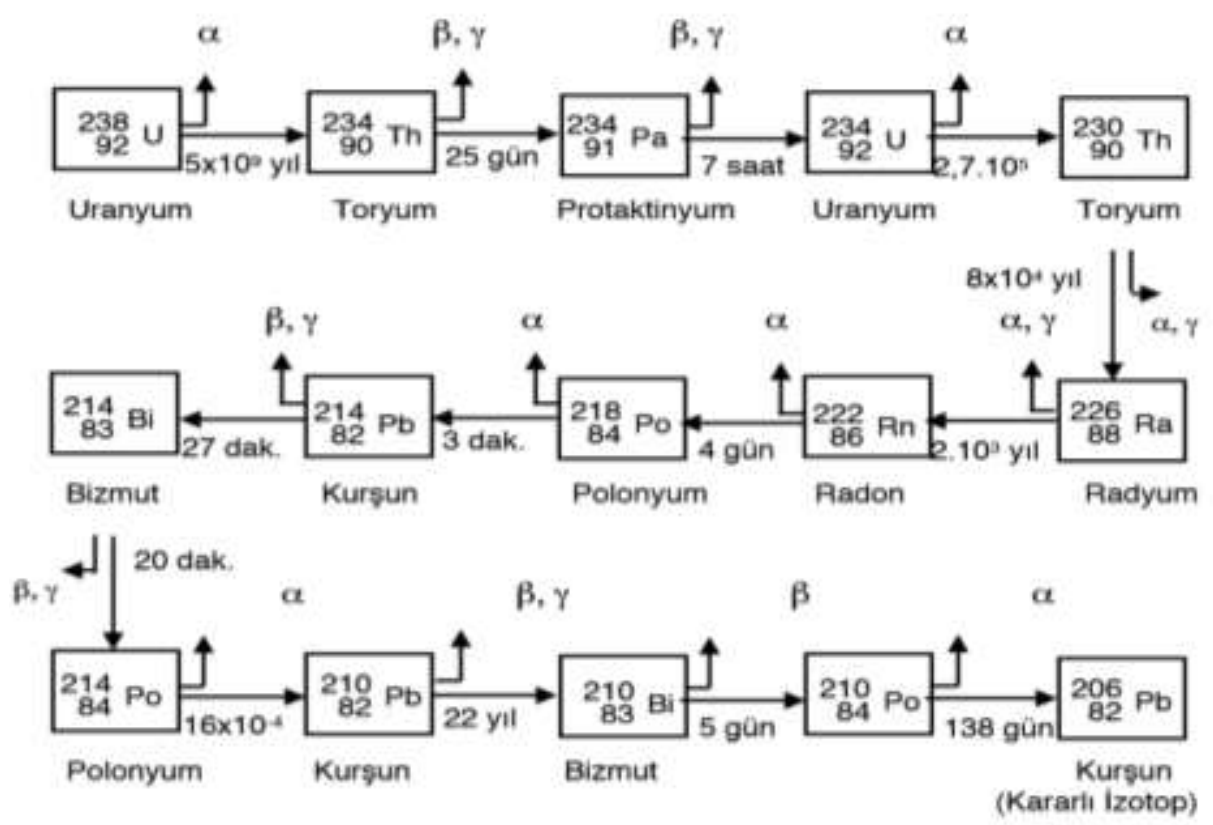

Şekil 1. Uranyumun bozunma zinciri [3].

${ }^{222} \mathrm{Rn}$, yarı ömrü 3,8 gün olup renksiz, tatsız ve kokusuz radyoaktif bir soy gazdır [4]. Radon havadan yaklaşık 7 kat daha ağırdır [5]. Tablo 1 'de ${ }^{222} \mathrm{Rn}$ ' nin fiziksel sabitleri verilmiştir. ${ }^{220} \mathrm{Rn}$ (toron) ise ${ }^{232} \mathrm{Th}$ 'un bozunum serisinde yer almaktadır [1]. ${ }^{220} \mathrm{Rn}, 55$ saniyelik çok kısa yarı ömüre sahip olduğundan doğal ortamda radona göre ihmal edilebilecek kadar az bulunur.

Tablo 1. ${ }^{222}$ Rn'nin fiziksel sabitleri.

\begin{tabular}{ll}
\hline Atom ağırlığı & 222 \\
Atom numarası & 86 \\
Kaynama noktası & $-62{ }^{0} \mathrm{C}$ \\
Kritik basınç & $6.28 \mathrm{MPa}$ \\
Yoğunluk & $0.00973 \mathrm{~g} \mathrm{~cm}^{-3}$ \\
Ergime noktası & $-71{ }^{\circ} \mathrm{C}$ \\
\hline
\end{tabular}

Topraktaki radon, bina zeminindeki çatlak ve boşluklar gibi yapısal kusurlardan dolayı bina içine kolaylıkla nüfuz edebilir. Radon, düşük konsantrasyonlarda olsa da yap1 malzemelerinde de bulunur. Binalarda beton veya duvarlarda kullanılan malzemelerin uranyum içerikleri iç mekan radon konsantrasyonunu büyük ölçüde etkileyebilir. Radonun suda çözünebilme yeteneği diğer soy gazlardan daha yüksektir. Bu nedenle yeraltı sularında yüksek konsantrasyonlarda radon bulunabilir. Bu ise yeraltı suyunu kullanan insanlarda önemli sağlık sorunları oluşturabilir. Ayrıca radon, sudan ayrışarak ortama yayılabilme özelliği göstermektedir. Evlerde doğal gazın kullanılması radon konsantrasyonunu artıran bir diğer etmendir. Radon doğalgazın içinden ayrışarak ortama yayılabilmektedir [6]. Mevsimsel değişiklikler, bina iç-dış basınç farkı, binanın bulunduğu ana kayanın özellikleri, bu kayanın geçirgenliği ve gözenekliliği, binanın toprakla temasta olduğu yüzeyin alanı, binanın yalıtımı, doğal gaz, ev içi havalandırma koşulları ve ev sakinlerinin yaşam tarzı radon konsantrasyonunu etkileyen faktörlerdir [1]. Şekil 2'de radonun evlere giriş yolları görülmektedir. Radondan kaynaklanan sağlık sorunlarının artmasının bir nedeni ise, enerji tasarrufu nedeniyle bina yalıtım sistemlerinin daha iyi hale getirilmesidir. Dolayısıyla, bina içine giren radon ortamda hapsedilmektedir. $\mathrm{Bu}$ ise radon konsantrasyonunu arttırmaktadır. Sigara içmeyen insanlarda görülen akciğer kanserinin sorumlusunun radon olduğu ifade edilmektedir. Uluslararası Kanser Araştırma Kurumu (IARC), radonu grup 1 kanserojen olarak sınıflandırmıştır [7]. Radon ortamdaki toz ve su damlacıklarına bağlanır. Bu toz ve su 
damlacıkları solunduğunda akciğerlerde birikir ve dokular alfa radyasyonuna maruz kalır. Sonuçta, dokunun DNA yapısı bozulur ve kansere neden olur [8,9]. Akciğer kanseri ile vücutta biriken dozlar arasında doğrusal bir ilişki vardır. Radon konsantrasyonunda $100 \mathrm{~Bq} \mathrm{~m}^{-3}$ lük bir artışın akciğer kanser riskini \% 8,4 oranında artırdığı bildirilmiştir [10]. Dünya sağlık örgütüne göre, akciğer kanseri nedenleri arasında radon sigaradan sonra ikinci sırada yer almaktadır [11]. Genelde insanlar zamanlarının \% 90'lık kısmını kapalı ortamlarda geçirdikleri için radona maruz kalmaları önemli bir problem olarak ortaya çıkmaktadır [12]. Radon araştırmaları 1984 yılında Türkiye Atom Enerjisi Kurumu tarafindan başlatılmıştır. Bu çalışmalar o zamandan beri devam etmektedir.

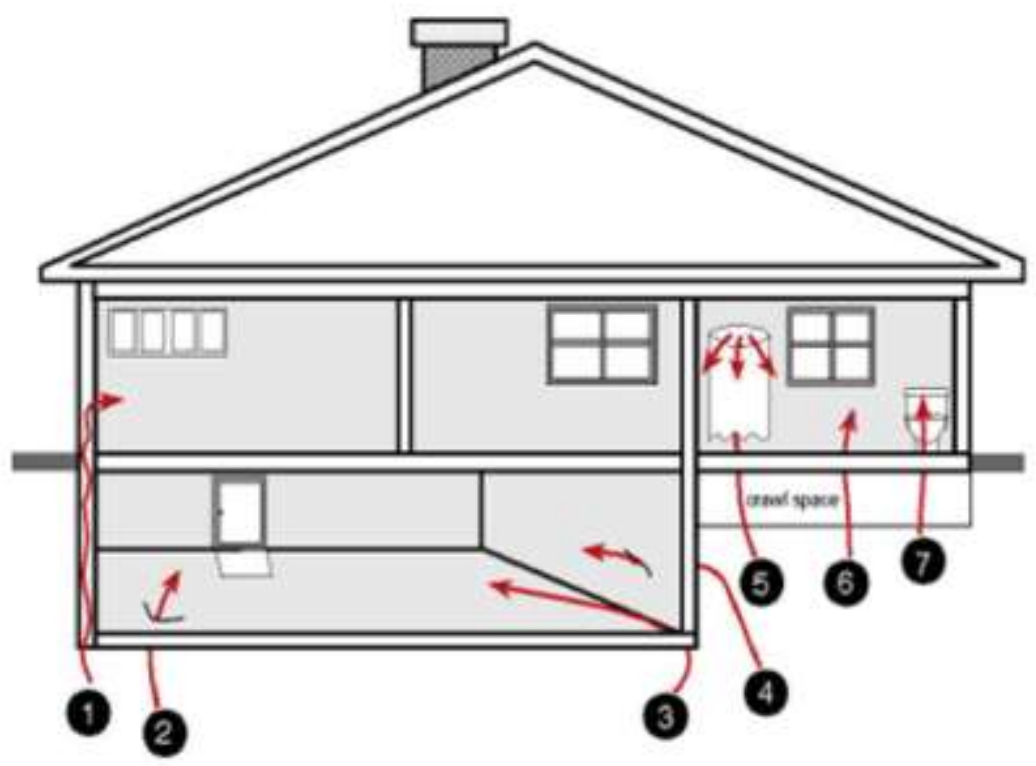

1- Duvar arası boşluklar

2- Zemindeki çatlaklar

3- Yapı bağlantı noktaları

4- Duvar çatlakları

5- Içme suyu

6- Asma kat boşluklar

7- Tesisat boru boşlukları

Şekil 2. Radonun ev ortamına giriş yolları [13]

Radon gazının ortamdaki düzeyinin doğru şekilde ölçülmesi radyasyondan korunma, uranyum aramaları ve depremlerin önceden saptanması çalışmaları için oldukça önemlidir [1]. Bu nedenle, son 20 yılda dünyanın pek çok ülkesinde kapsamlı araştırmalar yapılmaktadır $[14,4,5,15,16,17,18,19$, $20,21]$.

Bu çalışmanın amacı, evlerde radon aktivite konsantrasyonunu belirleyerek, radon solunumu ile alınan yıllık etkin doz eşdeğerini ve akciğer kanser risklerini hesaplamaktır.

\section{Materyal ve Metot}

\subsection{Radon Ölçüm Yöntemi}

Evlerde radon aktivite konsantrasyonu LR-115 pasif nükleer iz detektörler kullanılarak belirlenmiştir. Yöntem, LR-115 detektörü üzerine çarpan alfaların detektör üzerinde meydana getirdiği hasar sonucu gözle görülmeyen izler bırakması ve bu izlerin kimyasal iz kazıma işlemi ile büyütülerek optik mikroskopta sayılması esasına dayanmaktadır. LR-115 detektörler $2 \mathrm{~cm} \times 2 \mathrm{~cm}$ boyutlarında hazırlanarak kodlanmış ve plastik kaplara yerleştirilmiştir. Hazırlanan detektörler kış mevsimlerinde evlerde 30 gün boyunca bekletilmiştir. Detektör üzerinde oluşan izlerin optik mikroskopta görünür hale gelmesi için, detektörlere kimyasal iz kazıma işlemi uygulanmıştır. Bunun için \% $10 \mathrm{NaOH}$ çözeltisi hazırlanmış ve çözelti sıcaklığı $60{ }^{\circ} \mathrm{C}$ oluncaya kadar etüvde bekletilmiştir. Detektörler bu çözelti içine koyularak $60{ }^{\circ} \mathrm{C}$ sabit sıcaklıkta 95 dakika boyunca bekletilmiştir. Bu süre sonunda detektörler alınarak saf su ile yıkanmış ve kurutulmuştur. Detektör üzerinde oluşan izler 10x10 büyütmeli optik bir mikroskopta sayılmıştır. Detektör üzerindeki iz yoğunlukları iz sayısı $\mathrm{cm}^{-2}$ olarak belirlenmiştir. Detektörlerin kalibrasyonu, Türkiye Atom Enerjisi Kurumu (TAEK) Çekmece Nükleer Araştırma ve Eğitim Merkezi (ÇNAEM) Sağlık Fiziği Bölümünde bulunan radon kalibrasyon odasında yapıldı. 
Radon kalibrasyon odasında, $225 \mathrm{~L}$ ' lik bir varilin tabanında aktivite konsantrasyonu bilinen bir ${ }^{226} \mathrm{Ra}$ kaynağı bulunmaktadır. Radon kalibrasyon odasındaki aktivite $3.2 \mathrm{kBq} \mathrm{m}^{-3}$ dür. Kalibrasyon faktörü $3.40 \mathrm{iz} \mathrm{cm}^{-2}(\mathrm{kBq})^{-1} \mathrm{saat}^{-1} \mathrm{~m}^{3}$ olarak belirlenmiştir.

\subsection{Yıllık Etkin Doz Eşdeğeri}

Y1llık etkin doz eşdeğeri Eşitlik (1) kullanılarak hesaplanmıştır.

$\mathrm{YEDE}=\mathrm{RAC} \times \mathrm{F} \times \mathrm{T} \times \mathrm{D}$

Burada RAC radon aktivite konsantrasyonudur. F radon ve kısa yarı ömürlü bozunma ürünleri arasındaki denge faktörü olup bina içi ışınlanmalar için 0,4 ' dür. $T$ ev içi meşguliyet faktörü 0,8 (\% 80) dür. $\mathrm{D}$ ise doz dönüşüm faktörü olup değeri $9,0 \mathrm{nSv} \mathrm{h}^{-1} / \mathrm{Bq} \mathrm{m}^{-3}$ dür [1].

\subsection{Kanser Riski}

Yaşam boyu kanser riski Eşitlik (2) ile hesaplanmıştır.

$\mathrm{ELCR}=\mathrm{YEDE} \times \mathrm{DL} \times \mathrm{RF}$

Burada DL ortalama yaşam süresi olup 70 yıl alınmıştır. RF ise risk faktörüdür. Radona maruz kalan insanlardan elde edilen epidemiyolojik bulgular, akciğer kanseri için risk faktörünün radona maruz kalma süresine ve erişilen yaşa göre büyük ölçüde değiştiğini ortaya koymuştur. Bu bulgular ışığında, radon solunumundan kaynaklanan akciğer kanser riskini tahmin etmek için ICRP tarafından, halk için RF risk faktörü Sievert başına 0.05 olarak belirtilmiştir [22].

\subsection{Radon Konsantrasyonu Limit Değerleri}

Çeşitli ülkeler ve uluslararası kurumlar tarafından ev içi müsaade edilen radon aktivite konsantrasyonu limit değerleri Tablo 2'de verilmiştir. Ev içi radon konsantrasyonlarının düzenli aralıklarla ölçülerek limit değeri aşması durumunda önlemlerin alınması gerekmektedir.

Tablo 2. Çeşitli ülkeler ve uluslararası kuruluşlarca belirlenen radon aktivite konsantrasyonu

\begin{tabular}{|c|c|c|c|c|c|}
\hline \multicolumn{6}{|c|}{ limit değerleri $\left(\mathrm{Bq} \mathrm{m}^{-3}\right)[12]$. } \\
\hline A.B.D. & 150 & Hindistan & 150 & Norveç & 200 \\
\hline Almanya & 250 & İngiltere & 200 & Rusya & 200 \\
\hline Avustralya & 200 & İrlanda & 200 & Litvanya & 100 \\
\hline Çin & 200 & İsveç & 200 & TAEK & 400 \\
\hline Danimarka & 400 & Kanada & 800 & $\mathrm{AB}^{*}$ & 400 \\
\hline Fransa & 400 & Lüksemburg & 250 & ICRP** & 400 \\
\hline Finlandiya & 200 & İsviçre & 400 & $\mathrm{WHO} * * *$ & 100 \\
\hline
\end{tabular}

\section{Bulgular ve Tartışma}

$\mathrm{Bu}$ çalışmada evlerde belirlenen radon aktivite konsantrasyonları, yıllık etkin doz eşdeğerleri ve akciğer kanser riskleri Tablo 3'de verilmiştir. Evlerde biriken radon gazının ana kaynağı, binanın temas ettiği topraktaki uranyum ve türevleridir. Binanın temasta olduğu zemin toprağındaki uranyum içeriği, binanın iç ve dış cephesinde kullanılan malzemelerin uranyum içerikleri, binadaki dairelerin iç mekanında kullanılan malzemelerin uranyum içerikleri, havalandırma koşulları ve doğalgaz tesisatının yalıtımı radon konsantrasyonunu etkileyen parametrelerdir. Topraktan binaya radon girişi, binanın zemin, tuğla, beton ve çatlaklarından olduğu gibi bağlantı noktalarından ve binaya giren tesisat çevrelerindeki boşluklardan da olmaktadır. Tablo 3'den görüldügü gibi Kasımpaşa bölgesindeki binanın 1. katında 
radon aktivite konsantrasyonu diğer katlara nazaran daha yüksektir. 1. kattaki radon aktivitesi 4. kattaki radon aktivitesinden yaklaşık 3 kat daha yüksek belirlenmiştir. 6. ve 8 . katlarda radon konsantrasyonunun 4. kata göre daha yüksek olmasının nedeni, bina içinde ve dışında kullanılan yapı malzemelerinin aynı olduğu ve bu katlarda radon konsantrasyonunu artıracak farklı malzemelerin kullanılmadı̆̆ı göz önüne alındığında havalandırma koşulları olabilir. Bu durum havalandırma koşullarının radon konsantrasyonunu azaltmada ne kadar önemli olduğunu göstermektedir. Sefaköy' de 5. kat hariç diğer katlarda radon aktivite değeri üst katlara doğru azalmaktadır. 5. kattaki değerin yüksek olmasının nedeni benzer şekilde kötü havalandırma şartları ile açıklanabilir. Aynı şekilde, Esenyurt' ta binanın 2. katındaki radon aktivitesi 1. kata nazaran daha yüksek belirlenmiştir. Kapalı ortamlarda radonun izlenmesi amaciyla hem ülkeler hem de uluslararası kuruluşlar tarafindan sınır değerler getirilmiştir. Dünya sağl1k örgütü (WHO) tarafindan verilen limit değer $100 \mathrm{~Bq} \mathrm{~m}^{-3}$ dür [11]. Türkiye Atom Enerjisi Kurumu (TAEK) tarafindan müsaade edilen radon konsantrasyonu limit değeri $400 \mathrm{~Bq}$ $\mathrm{m}^{-3}$ [12] olup elde ettiğimiz tüm değerler bu limit değerin altında kalmaktadır. Dünya ortalamasına göre karşılaştırdığımızda, radon aktivite konsantrasyonları Kasımpaşa' daki binanın 4. ve 8. katı hariç diğer kat ve binalarda dünya ortalaması olan $46 \mathrm{~Bq} \mathrm{~m}^{-3}$ [1]'den daha yüksek elde edilmişsir. Şekil 3'de ise ilçelere göre radon aktivite konsantrasyonları verilmiş̧ir.

Tablo 3. Kasımpaşa, Sefaköy, Bahçeşehir, Bahçelievler ve Esenyurt semtlerindeki binalarda belirlenen radon aktivite konsantrasyonları ve kanser risk değerleri.

\begin{tabular}{|c|c|c|c|}
\hline & $\operatorname{RAC}\left(B q ~ m^{-3}\right)$ & YEDE (m Sv $\left.y^{-1}\right)$ & Kanser riski $\times 10^{-3}$ \\
\hline \multicolumn{4}{|l|}{ Kasımpaşa } \\
\hline 1. Kat & 100.40 & 2.53 & 8.86 \\
\hline 4. Kat & 31.88 & 0.80 & 0.28 \\
\hline 6. Kat & 49.96 & 1.26 & 4.41 \\
\hline 8.kat & 42.90 & 1.08 & 3.78 \\
\hline \multicolumn{4}{|l|}{ Sefaköy } \\
\hline 1.Kat & 66.57 & 1.68 & 5.88 \\
\hline 2.Kat & 63.13 & 1.59 & 5.57 \\
\hline 3.Kat & 56.24 & 1.42 & 4.97 \\
\hline 5.Kat & 125.48 & 3.17 & 11.10 \\
\hline \multicolumn{4}{|l|}{ Bahçeşehir } \\
\hline 7.Kat & 87.21 & 2.20 & 7.70 \\
\hline \multicolumn{4}{|l|}{ Bahçelievler } \\
\hline 1. Kat & 83.69 & 2.11 & 7.34 \\
\hline 5. Kat & 74.09 & 1.87 & 6.55 \\
\hline \multicolumn{4}{|l|}{ Esenyurt } \\
\hline 1. Kat & 90.82 & 2.29 & 8.02 \\
\hline 2. kat & 102.77 & 2.59 & 9.07 \\
\hline Ortalama & 75.01 & 1.89 & 6.43 \\
\hline Minimum & 31.88 & 0.80 & 0.28 \\
\hline Maksimum & 125.48 & 3.17 & 11.10 \\
\hline Medyan & 74.09 & 1.87 & 6.55 \\
\hline Standart Sapma & 26.65 & 0.67 & 2.77 \\
\hline Çarpıklık & 0.18 & 0.18 & -0.56 \\
\hline Basıklık & -0.47 & -0.45 & 0.95 \\
\hline p-değeri & 0.200 & 0.200 & 0.200 \\
\hline
\end{tabular}


Gürsel Karahan doktora tezi çalışmasında, İstanbul çevresinden aldığı 35 toprak örnekte ${ }^{226}$ Ra konsantrasyonlarını belirlemiştir [23]. Karahan, İstanbul toprağındaki ${ }^{226} \mathrm{Ra}$ aktivite konsantrasyonu dağılımlarının düzensiz olduğunu, aktivite değerlerinin birbirine çok yakın yerlerde bile farklılık gösterdiğini ifade etmiştir. Karahan' nın elde ettiği sonuçlara göre, toprakta ${ }^{226}$ Ra konsantrasyonları 7$66 \mathrm{~Bq} \mathrm{~kg}^{-1}$ olarak değişmektedir. Bu çalışmada, 5 ilçenin evlerinde belirlenen ortalama radon aktivite konsantrasyonu Kasımpaşa için $56.29 \mathrm{~Bq} \mathrm{~m}^{-3}$, Sefaköy için $77.86 \mathrm{~Bq} \mathrm{~m}^{-3}$, Bahçeşehir için $87.21 \mathrm{~Bq} \mathrm{~m}{ }^{-}$ 3, Bahçelievler için $78.89 \mathrm{~Bq} \mathrm{~m}^{-3}$ ve Esenyurt için $96.80 \mathrm{~Bq} \mathrm{~m}^{-3}$ olarak hesaplanmıştır. 5 ilçenin her biri için ortalama radon aktivite konsantrasyonları 56.29 - $96.80 \mathrm{~Bq} \mathrm{~m}^{-3}$ arasında farklı değerler almıştır.

İnsanların ev içinde maruz kaldıkları yıllık etkin doz eşdeğerleri Eşitlik (1) kullanılarak hesaplanmıştır. Tablo 3'de görüldüğü gibi, en yüksek ve en düşük yıllık doz eşdeğerleri $0.8 \mathrm{~m} \mathrm{~Sv} \mathrm{y}^{-1}$ ve $3.17 \mathrm{~m} \mathrm{~Sv} \mathrm{y}^{-1}$ olarak belirlenmiştir. Eşitlik (2) den ise kanser risk değerleri hesaplanmıştır. Tablo 3'de en düşük kanser risk değeri $0.28 \times 10^{-3}$ olup Kasımpaşa' daki binanın 4. katında gözlenmiştir. En yüksek değer ise $11.10 \times 10^{-3}$ ile Sefaköy' deki binanın 5. katında elde edilmiştir.

İstatistik parametreleri hesaplamak için (ortalama, medyan, standart sapma, çarpıklık ve basıklık) SPSS 21.0 istatistik programı kullanıldı. Basıklık ve çarpıklık değerleri verilerin normal dağılım gösterip göstermediğini ifade etmektedir. Çarpıklık değeri $=0$ ise normal dağılımdır. Çarpıklık değeri $<0$ ise sağa çarpık ve çarpıklık değeri $>0$ ise sola çarpık dağılıma işaret eder. Basıklık değeri normal dağılımda sıfırdır. Basıklık değeri $<0$ ise basık bir dağılım ve basıklık değeri $>0$ ise sivri dağılım vardır. Tablo 3 de, radon aktivite konsantrasyonu dağılımlarının hafif sola çarpık ve basık bir dağılıma sahip olduğu görülmektedir. Ayrıca, radon aktivite konsantrasyonlarının dağılımını test etmek için Kolmogorov-Smirnov normalite testi uyguland. Kolmogorov-Smirnov normalite testine göre $(\mathrm{p}>$ 0.05), binalarda belirlenen radon aktivite konsantrasyonları normal bir dağılım $(\mathrm{p}=0.200)$ göstermektedir.

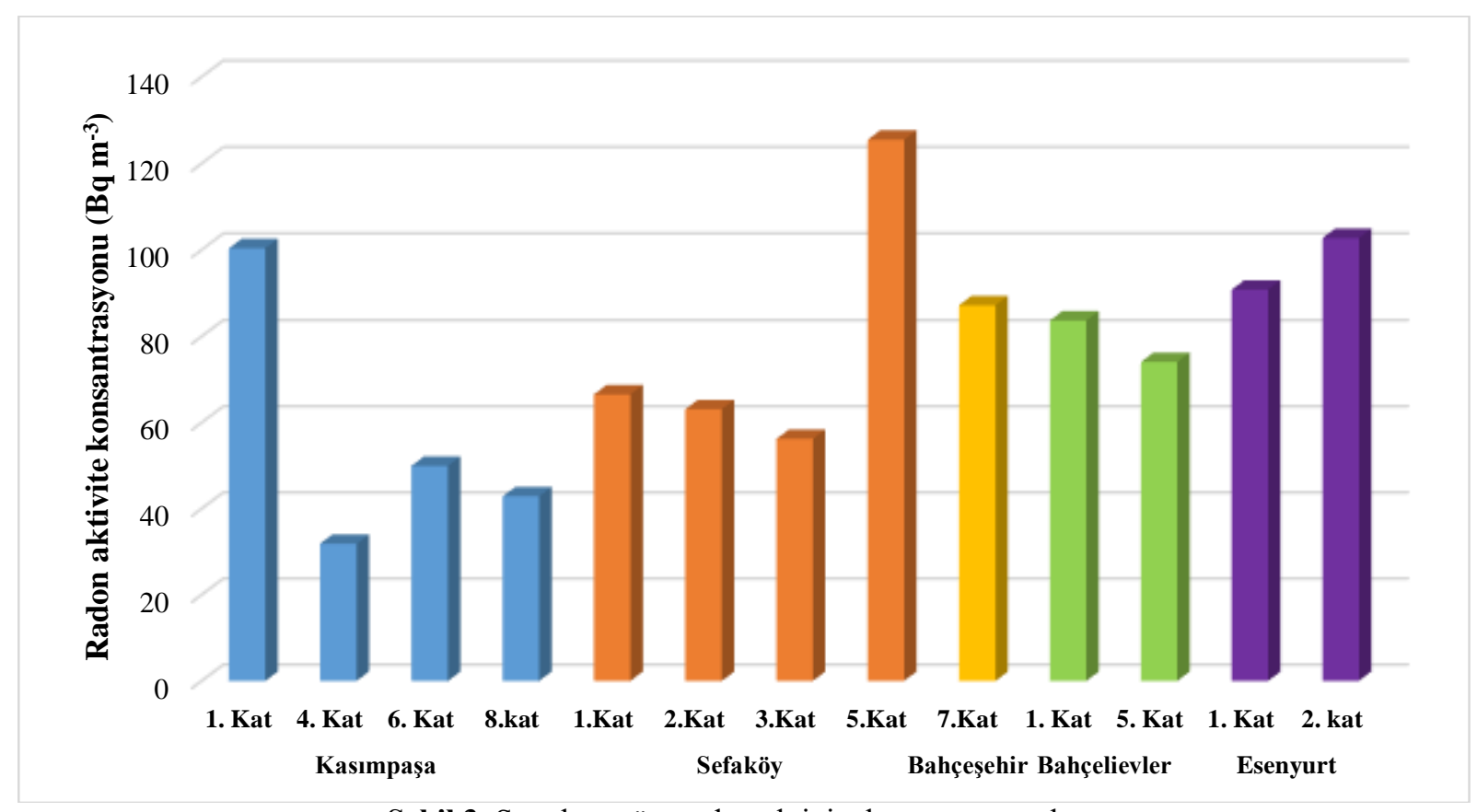

Şekil 3. Semtlere göre radon aktivite konsantrasyonları.

Türkiye' de farklı illerde yapılan radon çalışmaları ile ilgili bir literatür araştırması yapılmış olup sonuçlar Tablo 4. de verilmiştir. 
Tablo 4. Bu çalışmada İstanbul için belirlenen ortalama radon aktivite konsantrasyonunun literatürdeki çalışmaların sonuçları ile karşılaştırılması.

\begin{tabular}{lll}
\hline Bölge & RAC $\left(\mathbf{B q ~}^{-\mathbf{3}}\right)$ & Referanslar \\
\hline İstanbul & 75.01 & Bu Çalışma \\
Kestanbol & 65 & {$[24]$} \\
Manisa & 97 & {$[25]$} \\
Kırklareli & 71.01 & {$[26]$} \\
Kastamonu & 98.4 & {$[27]$} \\
Kars & 114 & {$[17]$} \\
Bayburt & 56 & {$[28]$} \\
Çanakkale & 167 & {$[29]$} \\
Erzincan & 53 & {$[18]$} \\
Kırıkkale & 74.25 & {$[30]$} \\
Karabük & 131.6 & {$[31]$} \\
Çankırı & 44 & {$[32]$} \\
Kilis & 50 & {$[19]$} \\
Türkiye Ortalaması & 81 & {$[20]$} \\
Dünya Ortalaması & 46 & {$[1]$} \\
\hline
\end{tabular}

Tablo 4'den görüldüğü gibi, bu çalışmada İstanbul için elde edilen ortalama radon aktivite konsantrasyonu Kestanbol [24], Kırklareli [26], Bayburt [28], Erzincan [18], Kırıkkale [30], Çankırı [32], Kilis [19] ve dünya ortalamasından [1] daha yüksektir.

\section{Sonuç ve Öneriler}

Elde edilen sonuçlara göre Kasımpaşa semtindeki binanın 1. katında, Sefaköy semtindeki binanın 5. katında ve Esenyurt semtindeki binanın 2. katında belirlenen radon konsantrasyonu WHO tarafindan belirlenen limit değerin üzerindedir. Bunun yanında, bu çalışmada elde edilen tüm radon konsantrasyonu değerleri TAEK tarafından müsaade edilen limit değerin altında kalmaktadır. Evlerde belirlenen radon aktivite konsantrasyonlarının endişe uyandıracak boyutlarda olmadığ 1 görülmüsstür. Daha detaylı çalışmaların 5 yılda bir periyodik aralıklarla yapılması gerekmektedir. Bina yapılırken kullanılacak yapı malzemelerinin araştııılması ve yapının inşa edileceği bölgenin radon haritasının çıkarılması oldukça önemlidir. Özellikle bodrum katlarının izolasyonu iyi yapılmalı, eski evlerde duvar çatlakları kapatılmalıdır. Bununla birlikte evlerde kötü havalandırma koşulları radona maruz kalmayı önemli ölçüde artırmaktadır. Radonun sağlı üzerindeki etkileri ve alınması gereken önlemler konusunda halkın bilgilendirilmesi de son derece önemlidir.

\section{Yazarların Katkısı}

$\mathrm{Bu}$ çalışmada tüm katkı yazara aittir.

\section{Çıkar Çatışması Beyanı}

Bu çalışmada yazarlar arasında herhangi bir çıkar çatışması bulunmamaktadır.

\section{Araştırma ve Yayın Etiği Beyanı}

Yapılan çalışmada araştırma ve yayın etiğine uyulmuştur. 


\section{Kaynaklar}

[1] UNSCEAR, 2000. United Nations Scientific Committee on the Effect of Atomic Radiation: Sources and Effects of Ionizing Radiation. Annex B, United Nations, New York.

[2] Tabar E., Yakut H., Saç M.M., Taşköprü C., İçhedef M., Kuş A. 2017. Natural radioactivity levels and related risk assessment in soil samples from Sakarya, Turkey. Journal of Radioanalytical and Nuclear Chemistry, 313: 249-259.

[3] Şahin M. 2019. Investigation of radioactivity levels of ${ }^{210} \mathrm{~Pb}$ and ${ }^{210} \mathrm{Po}$ in produced tobacco products in Turkey and the radiation dose by exposure - Development of adsorbent for the removal of ${ }^{210} \mathrm{~Pb}$. Doktora Tezi, Hacettepe Üniversitesi, Fen Bilimleri Enstitüsü, Ankara.

[4] Abd El-Zaher M., Fahmi N.M. 2008. Studying the variation of radon level in some houses in Alexandria City, Egypt. IX. Radiation Physics \& Protection Conference, 15-19 November, Nasr City - Cairo, Egypt, 339-347.

[5] Karpinska M., Mnich Z., Kapala J., Szpak A. 2009. The evaluation of indoor radon exposure in houses. Polish Journal of Environmental Studies, 18 (6): 1005-1012.

[6] UNSCEAR, 1988. United Nations Scientific Committee on the Effect of Atomic Radiation: Sources and Effects of Ionizing Radiation. Annex A, United Nations, New York.

[7] IARC, 2004. International Agency For Research On Cancer, Tobacco Smoke and Involuntary Smoking, IARC Monographs On The Evaluation Of Carcinogenic Risks To Humans. Lyon, 83.

[8] Apak H. 2014. Yapılarda radon etkisini azaltmaya ya da yok etmeye yönelik bir yaklaşım. Yüksek Lisans Tezi, Yıldız Teknik Üniversitesi, Fen Bilimleri Enstitüsü, İstanbul.

[9] Uludağ H. İ. 2010. Radon kirliliği ve halk sağlı̆̆ı ilişkisi. Bitirme Tezi, Ege Üniversitesi, Tıp Fakültesi, İzmir, 1-39, https://silo.tips/download/radon-krll-ve-halk-salii-lks. (Erişim Tarihi: 29.01.2021).

[10] Darby S. Hill D., Auvinen A., Barros-Dios J.M., Baysson H., Bochicchio F., Deo H., Falk R., Forastiere F., Hakama M., Heid I., Kreienbrock L., Kreuzer M., Lagarde F., Makelainen I., Murrhead C., Oberaigner W., Pershagen G., Ruano-Ravina A., Ruosteenoja E., Schaffrath Rosario A., Trrmarche M., Tomasek L., Whitley E., Wichmann H.E., Doll R. 2005. Radon in homes and risk of lung cancer: collaborative analysis of individual data from 13 European casecontrol studies. British Medical Journal, 330 (7485): 223-226.

[11] WHO, 2009. Handbook on indoor radon: a public health perspective. World Health Organization, Geneva.

[12] TAEK, 2012. Kapalı Ortamlarda Radon Gazı, Teknik Rapor, Ankara.

[13] Özkorucuklu S., Akyıldırım H., Çapalı V. 2006. Isparta İli'nde Radon Yoğunluk Ölçümleri. Süleyman Demirel Üniversitesi, Fen Bilimleri Enstitüsü Dergisi,10 (3): 323-327.

[14] Anne-Sophie E., Denis H., Solenne B., Dominique L., Eric J., Margot T., Jacqueline C. 2006. Childhood leukemia incidence and exposure to indoor radon, terrestrial and cosmic gamma radiation. Health Physics, 90 (6): 569-579.

[15] Köksal M.E., Çelebi N. 2003. Radon ve Türkiye evlerinde radon ölçümleri. Türkiye Atom Enerjisi Kurumu, Çekmece Nükleer Araştırma ve Eğitim Merkezi Yayını, İstanbul.

[16] Çelebi N. 1995. Çevresel örneklerde uranyum, radyum ve radon ölçüm tekniklerinin geliştirilmesi. Doktora Tezi, İstanbul Üniversitesi, Fen Bilimleri Enstitüsü, İstanbul.

[17] Çelik N., Poffijn A., Çevik U., Schepens L. 2008. Indoor radon survey in dwellings of the Kars province, Turkey. Radiation Protection Dosimetry, 128 (4): 432-436.

[18] Öztürk E., Küçükömeroğlu B., Yeşilbağ Y. O., Kurnaz A., Albayrak N., Taskın H. 2010. Indoor radon $\left({ }^{222} \mathrm{Rn}\right)$ concentration measurements in dwellings of the Erzincan province, Turkey. Azerbaijan Journal of Physics, 16 (2): 527-529.

[19] Can B., Canbazoğlu C., Albayrak N., Çelebi N., Doğru M. 2011. Measurements of indoor radon concentration levels in Kilis, Osmaniye and Antakya, Turkey durings spring season. Journal of Radioanalytical and Nuclear Chemistry, 292 (3): 1059-1063.

[20] Çelebi N., Ataksor B., Taşkın H., Bingöldağ A. N. 2015. Indoor radon measurements in Turkey dwellings. Radiation Protection Dosimetry, 167 (4): 626-632.

[21] Kahraman A., Poffijn A., Kaynak G. 2014. Measurement of radon level in dwellings of the Yıldırm County in Bursa. Acta Physica Polonica A, 125 (2): 268-270. 
[22] ICRP, 1990. Recommendations of the International Commission on Radiological Protection. ICRP, 21 (1-3).

[23] Karahan G. 1997. İstanbulun çevresel doğal radyoaktivitesinin tayini ve doğal radyasyonların yıllık etkin doz eşdeğerleri. Doktora Tezi, İstanbul Teknik Üniversitesi Nükleer Enerji Enstitüsü, İstanbul, 1-118.

[24] Çelebi N., Alkan H. 1997. Evaluation of natural radiation in the Kestanbol spa region. Radiation Protection Dosimetry, 69 (3): 227-230.

[25] Erees F., Aközcan S., Parlak Y., Çam S. 2006. Assessment of dose rates around Manisa (Turkey). Radiation Measurements, 41 (5): 598-601.

[26] Taşkın H. 2006. İnsan sağlı̆̆ı ve çevre kirliliği açısından Kırklareli ilinin fon radyasyonunun belirlenmesi ve haritalandırılması. Yüksek Lisans Tezi, Marmara Üniversitesi Sağlık Bilimleri Enstitüsü, İstanbul.

[27] Kam E., Bozkurt A. 2007. Environmental radioactivity measurements in the Kastamonu region of Northern Turkey. Applied Radiation and Isotopes, 65 (4): 440-444.

[28] Küçükömeroğlu B., Kurnaz A., Damla N., Çevik U., Çelebi N., Ataksor B., Taşkın H. 2009. Environmental radioactivity assessment for Bayburt, Turkey. Journal of Radiological Protection, 29 (3): 417-428.

[29] Kam E., Bozkurt A., Ilgar R. 2010. A study of background radioactivity level for Canakkale, Turkey. Environmental Monitoring and Assessment, 168 (1-4): 685-690.

[30] Bingöldağ N., Otansev P. 2018. Determination of natural radiation levels and lifetime cancer risk in Kırıkkale, Turkey. Radiochimica Acta, 106 (5): 401-411.

[31] Baldik R., Erer A.M., Aytekin H. 2011. Radioactivity measurements and radiation dose assessments due to natural radiation in Karabük (Turkey). Journal of Radioanalytical and Nuclear Chemistry, 289 (2): 297-302.

[32] Kapdan E., Taşkın H., Kam E., Osmanlıŏlu A.E., Karahan G., Bozkurt A. 2011. A study ofenvironmental radioactivity measurements for Çankırı, Turkey. Radiation Protection Dosimetry, 150 (3): 398-404. 